\title{
在弡展中的我國果樹生產事業
}

\author{
俞 德 浚
}

（中國科學院植物㭔究所）

我國是訢多重要果樹的原坣地, 果樹截培已 有二、三千年悠久糜史, 所以果品種類记繁多在 全世界佔第一位, 其中一部分果品如村梽、梉果、 荔枝、龍服、柲梁、胡桃等每年均有相當數量運 銷到國外。果品生常在荣些地區農村經演中佔着 很重要的地位。低在解放以前, 反動政府對於人 尼生產只有掠㖕制削, 而帝國主義國家文以不本 等條約作第侵略的武器向我國傾銷水果。每:年都

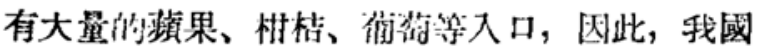
果樹生產的發展受到搌重的抑制和担等。

解倣以後，在中尖人上政府正確的宸業政策 指覒下，先注意鋉食和怗花的㙫產，解决了人民 的衣食問題。從1951年，起糧棉生產已經㿞到或超 過戰前年代的最演水本。篇了改善人民生活, 篇

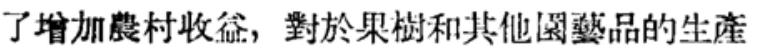

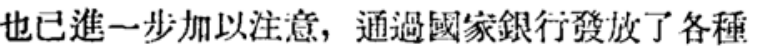
生倠貸款, 農林部門加强技術指導, 協助果票撲 诚病路害, 國營留易部門领導合作社和私商展開 城鄉物資交流, 煚多種乾鮮果品在國內國外找到

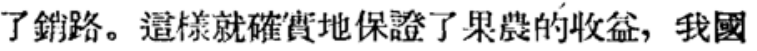
果樹生有事業從此走上了秎步發展的道路。

我們的盟邦蕉禾聯, 去作秋季會派遣專家四人 柬我國考察脤業園藝生產事業。中央農業部聯合

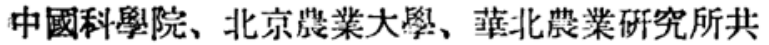

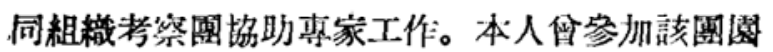

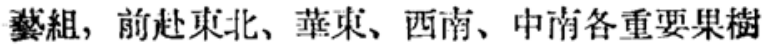

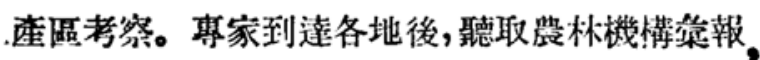
參觀各公營私管果園、莀事試驗埸、農科研究

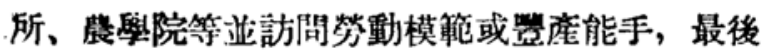
座談總結。專家們本着偉大國際主義的精神, 針對 現實問题，提出很多窑贵意見。本签是就倜人記 錄與體會所及，把造次考察作一倀摘要的報導，
內容色括一般産物情况、果樹種類和分布情况、 登盖經營方式、存在問題和專家在座談中指示出 米的解次途徑。我國已經開始了大規模經淳建 設, 果樹生澱是宸業生産中的重要一環, 這次蘇 聯專家的意見, 對於在發展中的我國果樹生虐事 業一定會發生重大的啓發和指導作用。因此, 本 人見聞雖然有限, 仍願把僄次考察經過作一綜合

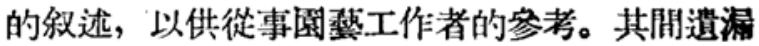
錯誤之處，份有待各地工作同志的批評指正。

\section{一 東北區}

1.一般情况 依照自然佟作和產物情况, 全 東北區可以分篇南溯和北滿兩部分: 南滿氣候較

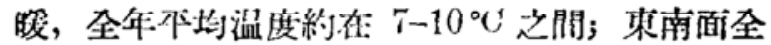
年雨量約 800 喜米, 待酒北的逐潮減少, 接近內

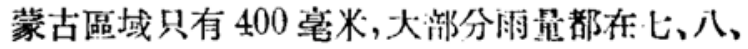
九三湖月間, 無霜期約 180-200 天; 土壤多第棕 壤和灰棕壤。南滿的農作物以高粱第太王, 政子次之, 特種作物有棉花和洋麻, 果溦有数 果、梨、桃、菒、李、苻萄等。北滿氣候較冷, 全年平均温度約在 $45^{\circ} \mathrm{C}$ 之䦌, 企年 雨 量 約有

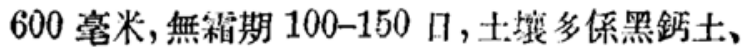

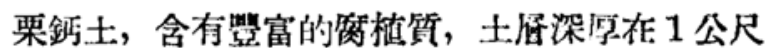
以上。北滿的作物以小麥、大豆篇主, 特種作物 有亞旅、大椨，果樹僅有梨、李、海棠、樹学等 少数種類。

2. 果樹種類 乘北區的果䅌以蓝果、梨第大 宗, 其他萷荇、桃、李、桀、胡桃、榛子、板栗 等各有少量出流。

濒果主要分布在遼東省的復憬、盖平、海 城、新金、大連、旅順等地和癷西省的錦州、與 城等地。品種很多, 大部分是絕由日本介紹來的 
洋濒果, 較好的有十幾個品種。早等種以紅鬼、 黄䰠篇主, 約在 7 月下句成熟; 中熟種以院、金 冠、元帜、紅玉等篇主, 約在 8 月中、下旬成 熱; 晚熟種有國光、倭錦、印度、紗冠、醇露等 等, 成熟期約在 10 月中下旬。在植株數量上, 國光佔第一位, 主要原因是國光濒果酎储藏, 健 於遠運。其次紅玉、'倭錦、元船、金冠也相當普 掘。全區共有頻果樹約 500 萬株, 其中五分之二 已結果, 五分之三還是新截份未結果的幼樹。設 以每株平均產量 70 厅咶 (根摭大速統計数字) 本 區全年至少可浐濒果 $1 \pm 0$ 笉担。

梨主産在迩西省汭錦縣、䋨中、北鋇、皒 䅫、錦西和熱河省的興隆、承德、建昌等地。品 種多係本國種, 包括秋子梨系統和白梨系統, 是秋 子梨系統的主要分布區域。在産量上以秋子梨、 秋白悡、鴨兒梨雼最多, 其次第紶梨、妿梨、概 梨、雪水梨等, 成嘽期在 8 月下的到 9 月上旬, 近年引種的西洋梨和日本梨佔亟少數。全㒑約有 梨樹 500 䉓株, 結果樹在牛數以上, 产量缺乏正 確統計, 但和蘋果全年産量應䠹相去不薏。

蔽蓗主產在遼東省的熊岳和旅大地區, 遼西 和熱河兩省也有少量出產。主要品種第玫瑰香、 龍报、白牛奶、紅牛奶等, 成㜪期多数在 9 月下 旬到 10 月上旬。全區約有蒱植 11 荡株, 設以每 株平均产量 13 斤計（根摭大連統計數字), 全年 約可產蒪落 14,300 担。

3.經䂏情况 東北區栽培蘋果不過五、六十 年的歷史, 大部分裁在平原地上, 少數利用川坡

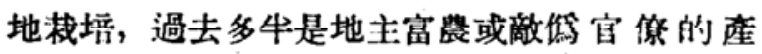
業。但梨的裁培歷史很久, 多數分布在川地, 主

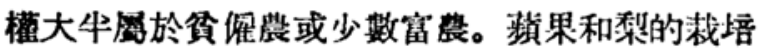
管理方法也有很多不同。耤果園的中耕、除草、

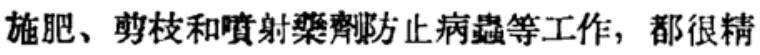
細週到; 但梨一般比較粗放, 多数不项然, 施肥 與否不定, 除去每年把枯枝和生長過密的枝條砍 去一些以外, 就沒有什窟修剪工作。在遼西省錦 西縣餵牛場有很多老梨樹, 那個地方栽培梨樹至 少已有 250 年以上的歷史。辳比們皘照了多年經 驗創造一種在川地種植果樹的方法, 所謂 “撩埙

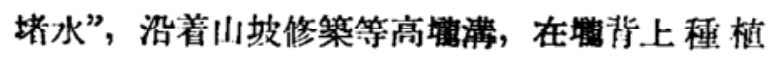
梨樹。有效地防止了土壤的冲㓢, 保存了雨水從 而保證了果樹優良的生長和結果。在一般的情形

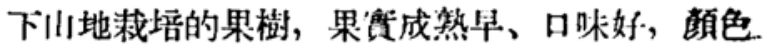

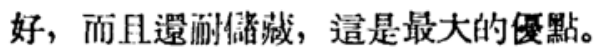

在國上黨反動統治時期, 一切生高事業汥有 保障, 人上涊有生産信心, 不䝠意投資, 也浔有 力量投資在果樹上。很多果園都逐漸筦挂起來。

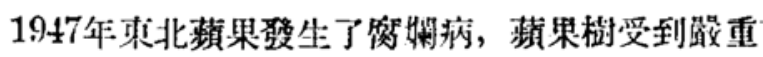
的破坮與損火。原來東北區有六百多苟株濒果 樹, 其中三分之一因患寉桐病而枯死。現在殘存 的蔳果樹, 雖然在解放後經過賞地政府領導大力

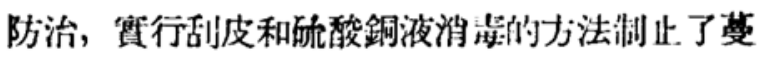
延, 但現存的樹株還有很多不健全, 有的大樹只 剩下了牛這或僅有一、二主忮在活着, 其餘部分 已絓被砍掉。

土改以後, 一些地主富農的大果圆和敵㙳的 轮業一部分改筬公營果園, 一部分则分給贫倠㖘。 去生產。但由於樹勢强强、地勢好壞、品種不 同, 很難分配。有時一家分得果樹 $\mathrm{f}$ 、六十株却 分散在幾发, 很不好經營, 阔時资何器凘本短 少, 又缺泛經營技術, 闪此從 1948 年起當地政府 號召“組織赸來搞好生產”, 少後成立了很多合作 果園, 有的是生產合作, 有的互助合作, 也有供 銷合作。東北現在已有二百多合作果園, 基礎相

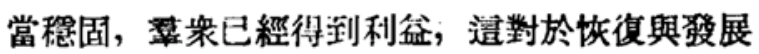
果樹生產起了很大的推動作用。

例如旅大區金縣八里村王洪元生產合作触, 他們原来都是替地主抗衫照管果園的工人, 土改 後翻身作了主人。但因果園分開不好管理, 在黨 的領葓下從 1949 年起就成立了互助組。全粗共 有五戶，川地果图 53 畧，1951 年起更擴充篇生 產合作社, 全牴現有十戸，36人，果園酒皘坦加 到 156 畧, 果樹有二千多株, 其中有蘋果 1,766 株, 桃樹 592 株, 邆有少数梨、杏、贸桃和海棠。1952: 年堂量佔計有 16 萢厅, 比 1951 年提高了一倍,

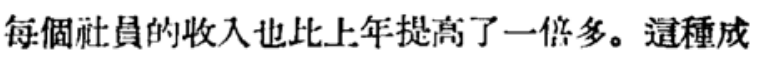
縝明確的指出來, 今後果樹生産必須走.上.合作, 走上集體經營的途徑。

4. 存在問題 蘇聯専家根據在熊兵、大連、

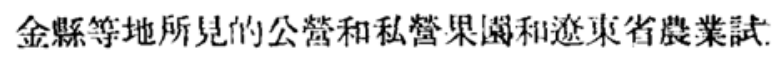

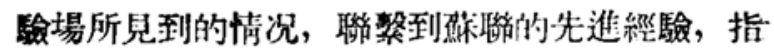
出了存在着的問题, 提出了很多富贵意見。

蘇聯專家認第在来北發展川坡地果園有很入 的希望, 㮣該注意研究造调問題。雇該深入豆衆。 
研究亚總結掌衆經驗, 在科學基礎上加以提高。 由於川坡地裁培果樹和平地不同, 應該注意品種 和砧木的選擇、梯田的修築、病题害的防治等重

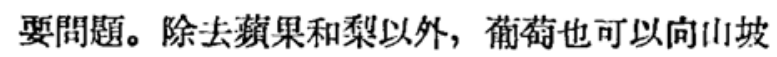
地發展, 大量生產, 供給酸造工業的需要。

在發展果樹栽培事業中, 繁殖苗林是很重要 的工作。東北目前所用的育苗方法需待改進之處 很多。各種蘋果砧木一律用山荊子, 作第接穗的 母樹, 汥有經過噘格的選撰, 嫁接過後的苗木一 年即行出闻, 很多單幹而不分枝, 有些苗浦且將 在生長季節中所發生的副梢剪去。蘇聯國䂏嗨阑 現在向外推廣的藕果苗水都是二年生的, 苗不在 苗固中必須完成合於規格的整枝工作，推廣的苗 木必須符合一定的規格, 保證具有离度的品質, 也就是保證了葬衆的利盆, 使果樹生產事業得以 正確迅速發展。

果樹的整枝修学並沒有一定的形式和方法, 只有在進行了適常的施肥使枝装有足量的發展之 後, 才能談到修剪, 只有在合理的修剪全面地配 合一系列的䔶業技術的條件之下才能獲得倣額產 量。東北現在培植蘋果過度重視修剪们形式和效 力, 而脱離了其他的㖘業技術是隹硋料正的㣂 向。在大連附近有些蒲䔨園一律探归立架, 惯行强 度修岦, 結果枝留得太短, 以致絬梁的部位都局限

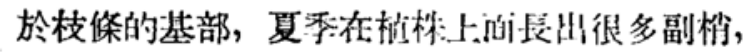
梢上結果, 但不能成熟, 没蓣了物力, 大大的

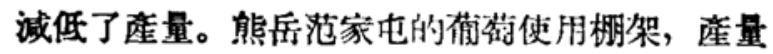
相當增加, 但有些農民不知近如何把結果母伎更 新, 經過二、三十年就將根枝据去另栽新苗, 道 樣也造成了浪費。

關於熊岳試驗埸荹果育種問題, 專家指出現 有的蘋果品種多數是美國品種, 其中有些生長不 好, 不適於本地風土。在息樣的條件下, 不能保 登會有侵良的成綪。我們必須一方面收集本地的 材料, 另方面從其他地品引入新品種, 進行遠方 品種雜交, 才可以炛望能獲得優良的、合於我們 所需要的、適合賞地環境的品種。新種苗得到之

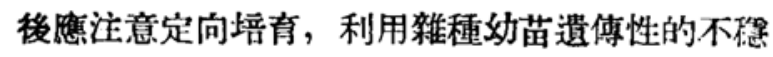
定性, 使用蒙導法加强某些!海狀的發育。在確定 了雜喠的優越性之後始可進行繁殖。

在考察的幾個蘋果園中，金數三十里堡高志 隆所經營的蘋果園是非常成功的。樹株生長旺
盛, 病蟲害極少, 7 嘼地的面積, 頻果樹 120 株, 三年來產量經常在三萬厅以上，基本上克服了隔 年結果的現象。金縣第一農場第九梁園的大國光:

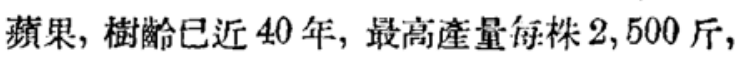
大速嶺前區第而二果園王順同志的兩架带荇, 每

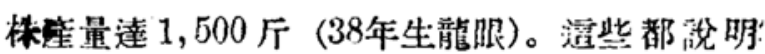

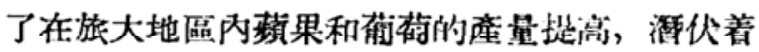
極大们可能性。要充分的發揮逼種洴在的能力必

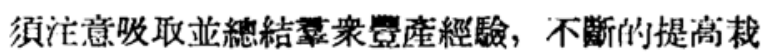
培管理的技術，才能有更廣閝的前途。

\section{二 華東區}

1. 一般情况 華東區整偑地形狹長，䵧候雨 量土媛等自然環境差界很大。川東風土近似寒温 帶的華北, 全年平均温度 $12-14.6^{\circ} \mathrm{C}$; 福建近似 亞熱帶的廣東, 全年平均滥度的在 $19-21.7^{\circ} \mathrm{O}$ 之 間。的量自北待南也逐漸/加多，例如以東北部丽 量全年不過 400-500 毫米, 到魯南皖北增加到 600-700 毫米, 浙北雨量 $1,000-1,200$ 筞米, 浙 江和䄼建沿海各地雨量可到 1, 300-1, 500 㲠米, 在福建山區雨量特别窝宾可到 1,600 毫米。

我们暫以淮河篇界, 將華束區分篇南北雨

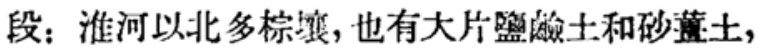
主要作物有小麥、数子、大豆、高桹、椎花、花

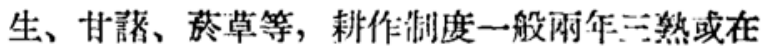
灌溉之區一年雨熟。淮河以南多篇酸性的紅壤和 灰棕壤, 沿海一帶有大片沖積土, 夏季作物篇水 稻，冬季作物有大麥、小麥、篦豆等。含透的區 域多種棉麻, 耕作制度一年兩熟, 少數地區第一

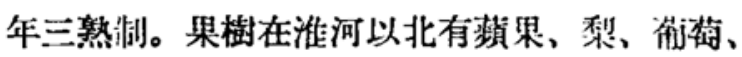
费、柿、桃、等; 淮河以南自淮河流域到踐瞊汇口流 域之間水果種類較少, 主要篇桃、暀與比杷, 浙南 到福建省出産多種村桔和否蕉、荕枝、龍眼等等。

2. 果樹種類 本區各省皆有果品生港, 但以 山東、浙江、福建三省第重點。

川束果樹 種類很 多, 有蘋果、蒱蕧、梨、 柿、轰等。蘋果可分本地品種和外國 品種丽大 類: 本地品種主產在鲁中和鱼東南部, 如沂水、 蒙䧔、新泰、䔉焦等地; 外國品種分布在膠來牛岛 文登、湽陽、掖影、煙台、青帛等地; 外國品種 中較好的篇青番焦、國光、秋花皮, 元扸、紅金 絲、紅星、金婂、紅玉、航等。據華東莀林部初步統。 


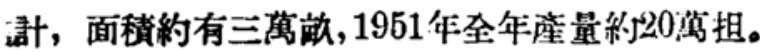
梨有七、八十種, 大多数屬於白梨系統, 其 中最主要的篇莱陽花梨, 肉細味甜, 品質很好, 9 月中下旬成熟, 博川池梨、德州鴨梨、黄縣長

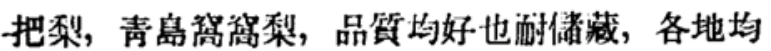
有大量截培。少量的有鹅梨、秋白梨、洋梨、子 母梨和金陶子梨等。據不完全統計，長把梨全年 荲量的 23,500 担，萑梨年产約 16,000 担。

桃有十餘個品種, 其中以肥城桃最負盛名, 品缶很好, 9月上旬成熟。其次有青州水絲桃、五 月紅、六月鮮等品種。

霖子品種很多, 全省各地皆有裁培。其中以 樂酸的無核霜和金絲小霞最負盛名, 皮薄肉厚含 跲分高, 適於加工之用, 年㘱約 8,000 担, 莲銷 各地。此外大量栽培的還有長紅费和圆鉿霜, 產 愁中南山區, 數量較小的有木霖, 婆桨, 冬然, 㓋表等等。

涌得主要產地在掖南、平度、烟台、青島等地, 品種有玫瑰香、龍哏、白玫鉏、牛奶等, 山地產 者大分供酷酒之用。

在山東的山區另外有一重要果樹是柿子，主 要品種有牛心柿、㦄盤柿、㖇胡柿等, 分布在博山、 泣南、泰安、㿽都等地, 除生食外, 大部分乾製 作柿餅遠運銷售各地。

浙江省果樹以㜀枮篇主, 分布在黄岩、温州、 街縣三地區。黃岩村枮多裁培在澄江兩岸, 靠潮 汐沖刷灌溉, 供給大量有機質。嫁接繁殖, 用釣 頭橙作砧木。主要品種有早榬（或名黄岩蜜榙、

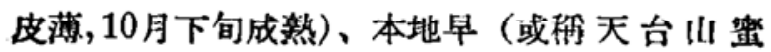
桔, 味較早桔甜美, 品質很好, 11 月中旬成熟)、 梫桔（成熟遲, 酎储藏, 12月上.旬成熟), 其次

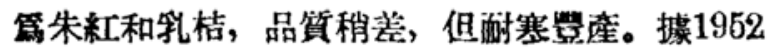
年統計約有 120 萬株, 全年總䃏量約 48 萬担。

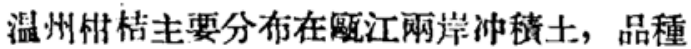

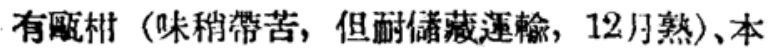
地材(皮薄品質較好, 但不解储藏) 等。1952 年 估計产量約篇四萬担。

得路湘栺主要分布在沿常山江兩岸的冲積平 原和邱陵地帶。因篇虽地材桔多用筫生繁殖, 所 以品種品系很雜。例如本地裁培最多的朱拮有大 籸（粗皮恄）、二紅（細皮桔）、七錢紅等品系、 0 月中下旬成熟; 其次篇福恄, 有早福桔（楊
桔)、鼠稫棈（漳桔）兩大品系，成䓡期在 $9 、 10$ 月間及11月中下旬。還有廣桔盗於甜橙類, 果大,

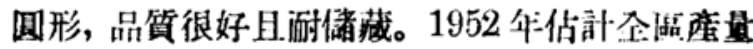
篇 14 藻担。

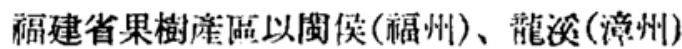

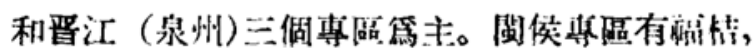

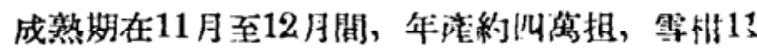

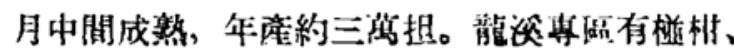

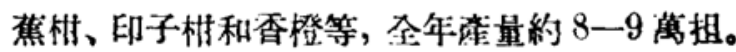
此外還有少量的龍眼、落枝、香蕉等然膫水果。

3. 經營情况川東是本活重要果樹炜满之 一，根據“中国賢業誌”紀栈，1933 年川東果樹共 有 2,271 荡株, 全年產量篇 1,700 英担。由於戰争

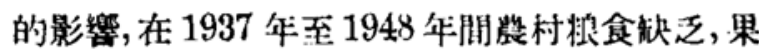

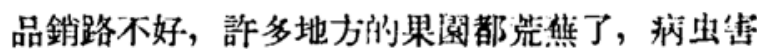
也䈯重起來; 京時有些地方直接进受口寇们破壞, 沿公路爾側的果樹大部分被砍伐掉，至今樂陵们

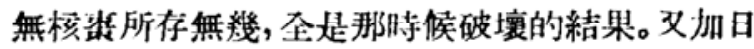
寇把口本濒果向我國倾釷'，膠束一帶濒果園人受

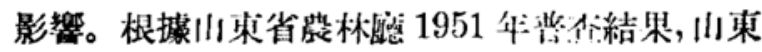
果樹株數比 1933 年減少 $50 \%$ ，呰暏減少 $70 \%$ 。

解放初期，人上此府奖集的力量解决人上约

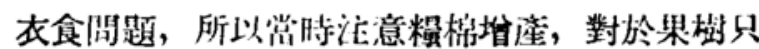
能暫時探取保磼恢復。1950 年後全國粗食 人器

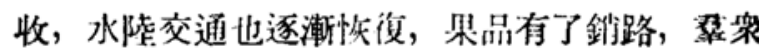
對於香樹䋑營有了信心。現在川果街人地政所對 於果樹已經從保荽恢復進人了發展階段，探取了 下列的一些措施：由政府投資成立了若干公營果 園, 大量培有消木, 提倡民堭命作經營, 充賽各

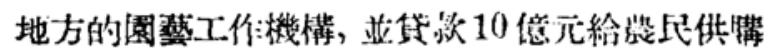

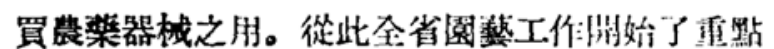
的發展, 果品生商也有了轉機。㨜初少佔犃 1950 年全年果樹硝量篇 320 䔽担, 1951 年㨦到 400 䔽 担, 1952年叮以堆加到 500 沼担。

在浙江省因篇從 1951 年起枯桔開始外銷, 更 刺激農尼重視染品生產, 各地方紛秎開閐土地種

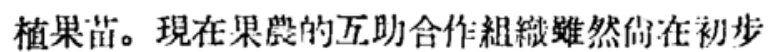
的階段, 但在個別經營中, 已济現了很多焉産能

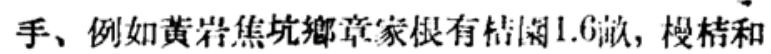
本地早抬等果樹人小其 83 株, 全年收獾在 6,000 斤以上, 又如黄茅何小章有地 0.66 故種植槾棈 36 株, 1951 年收獲了 3,000 斤, 1952 年收獲了 4,900 
斤, 他們掌握了適宜的施肥、除虫等技街, 所以 才能保持年年的高額產量。更由於外銷帶動了整 個㢈銷工作，在黨的領導下黄岩縣襄成立了生産 指導委員會召開了棈農代表會, 組織工作隊深入 農村宣傳呚育, 指導探摘技術, 粗織摹衆成立對 探售小組和農民䆩桔小組, 按着一定洔期, 按着預 定數量分批出售給土﨎公司或合作社領導組織的 收靕站, 此外在全影設立了八個加工廠担任分䄲 伦裝等工作。這一系列的栃㯰, 從生產到運銷, 就把整個黃炭沁城鋇鄉村都活躍起來了。

4. 存在问超 專家在山東考察了樂陵们榤和

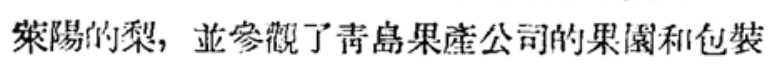

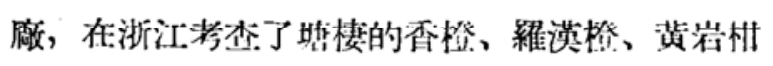

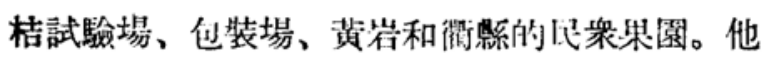
們在座談中提出寶贵意胃, 對於今後工作方向和 工作方法很多重要指示, 此地僅作摘要叙述。

资在樂陵的辳業生崀中佔着很大的比重, 無

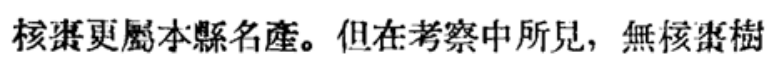
零星散布, 株數有限, 一般冰樹樹冠很小, 病虫 害相當多, 修剪技进粗放, 除去在行間作物上施 肥外, 桨樹不施肥, 所以專樹的單株産量很低。專 家指出如果在栽埍茂街上稍加改進, 焏的產量可 以火大提高, 如果在加工上予以改善, 则將來不 僅可以啺銷國內各地, 在國際访場上, 也可以取得 優越的地位。第了捉高加工技街和產品的質量, 今後應該创薄濃上走向集體生産和合作加工的方 向, 或由政府收購後集中進行加工。

蒋陽花梨的品質很好, 但品系複雜, 好壤相 崖很多, 應該再加以評選, 提高一步。值得注意 的是一般梨和蘋果結果地位主要在短果技上, 但 茌梨効不闹, 在一年生枝條的側㳊就可以分化花

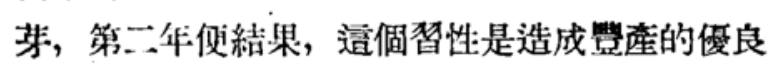
蓧件。但現在所用盤狀整枝的方法抑制了果樹的 旮分弡有, 結果确皘縮小, 減低了產量。萊陽梨 的梨賽蜂篇害最重, 脤民用搯花法防治。專家認 第這個工作需要很多勞動力, 太不經流, 應注澺 研究害出生活史和發生規律作有效的防治。政府

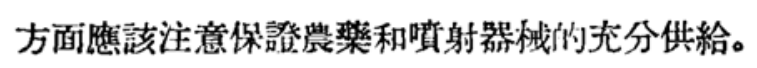

在萊陽和樂陵所昆到的果樹, 多數樹齡都在

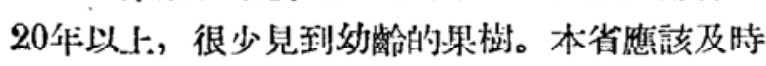
的把果農組織起來成立生産合作社, 㓦始入量繁 殖優良的苗木，㵠大果樹夜培。目前本省步润所
出的苗木, 不論質與量都不能滿足將來的要求。 專家特别介紹了蘇聯培育幼苗的先進經驗: 在蘇 聯不論砧木種類或作篇接穗用的母樹都必須經過 㭠重選摆。推廣用苗木的高度, 分枝和根系必須 都争合一定的標準, 始准出苗。

在照品的渾銷上, 過去注意得很不够。由於 汥有很好組織訂購的工作, 果品銷路不暢, 使莱 陽梨的發展陷於停頓。例如在花梨產區顔兒港每

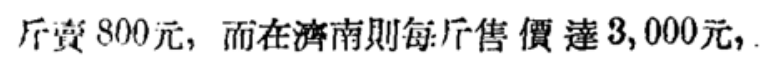
選樣美别是不㤫有的現象。在蘇聯生產者應得倍 偪 $75 \%$ ，運銷者得 $25 \%$ ，但此地则正好相反。及 萊陽梨一般在沒有成欮之前就探收下来, 過早的 探收合降低果買的品質, 造種現像也說明果農對 運釷沒有信心。專家建議本省和專啫的領導同志 應唼在運錎一的組䅧上和包裝的技術上研究改進, 大力展開銷路, 增加果碾的收益。

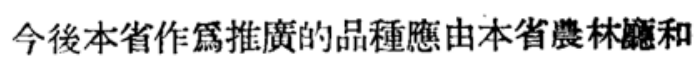

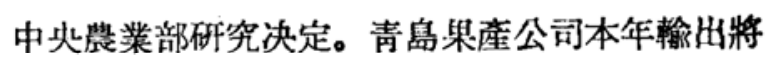
近 2,000 噸的蘋果, 其中紅星佔 $40 \%$, 這個品種不 耐储藏, 在運輸途中可能樊啠損失, 今後發展應 該注意酎運輸、耐储藏的品種。漖果佔全部果樹" 總株數中 $20 \%$, 但主要品種只有三個, 即金冠、

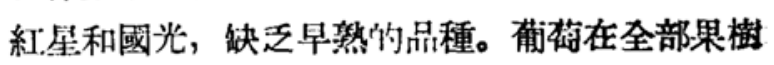
中只佔 $1 \%$, 不能够滿足本市人民的篮要。桃樹踓. 佔總株數 $37 \%$, 但成熟期很短, 今後應該注意成 熟期造早不同的品種, 延長供應期限。

黄岩和䧿縣的林桔, 大小年現像很普遍。事. 家指出主要原因是當地缺乏樹冠的管理和沒有一 定的施肥䔣度, 已澾結果年龄的果樹缺乏營荟, 在結果年形成新稍少而且生長弱, 因此翌年不能. 結果。蘇聯的柑桔修剪一般在 3 月舉行, 此外在 生長季䇤随時注意在必要的時候及時修剪。對於 六、七年以下的幼樹, 注意形成發育良好的樹冠。 對結果盛期的果樹, 主要在調整結果枝條與生辰 枝條的正常關係, 使生長平衡, 保持 $50 \%$ 結果枝 和 $50 \%$ 的新稍, 果樹便可年年結果。對於 25 年 以上的老樹, 必須淮行更新修剪, 以增加樹龄提 高產量。總之, 正確的修剪和及時的施肥是一套 綜合的農業技術, 各地品必須組織園藝專家和有 經驗的果農結合行政深入進行果樹的生物學特性

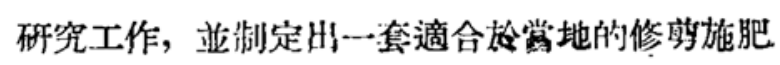
制度推廣給脿民。 
各地病虫害普遍嚴重, 如黄岩柑桔在 1951 年 㖟惡性棐出、吉丁出、介款出等第害, 減㡾了 $35 \%$, 並降低了果品的規格, 影響了外銷的数量。微影

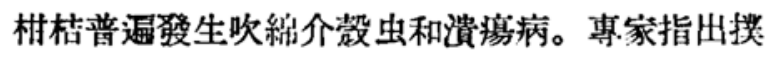
琙病出必須加强果樹的裁培管理, 並根據常地條 件研究病虫害的生派史和發生的根源與规律, 例 定出有效的防治方法。

現在黄岩農家所栽培的品種很多品顊不齊, 其中朱桔、乳桔品質不好, 應該逐漸淘汰, 換種 經法僄值較高的品種, 例如温州蜜柑、早熟甜橙 和在國際市場有廣大銷路的棬槽。在温州蜜柑的 樹冠上辰可以高接棕檬, 在正確的修苭和施肥下

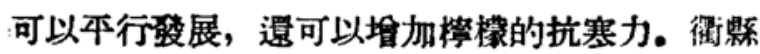
常山兩地交通便利, 氣候攸件亟適宜村枯裁夁,

果實成要期較早, 有些品質很好, 而且附近的山品 已秋的和未秋的可供裁培, 柑桔的面積可以拱古 而不致影響其他患作物, 今後弡展前途比黄岩大。 不過因䉆衙縣常山兩地均用種秄繁殖, 因此问一 品種中各品系間各單株間的美别很大, 應該由科 藇工作者聯合經驗㗼富的農民進行株選工作，再 行大量繁殖。繁殖的品種其數目應第三、五個, 不能多於五個, 這樣才能使其商品化。

專家指出, 中國具有害富的村桔種類和品種, 通是一個極好的基礎, 如果能够正確運用米后林 的理論和方法, 一定可以育出很多優良的品種。 篇了解决目前生産上的需要, 應該先從株選工作 着手。黃岩林桔場進行了胳橙、温州蜜林、本地 早桔、新會橙、劉勤光等品種之間相互嫁接, 希

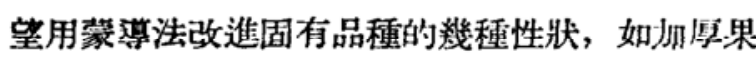
皮以改進聍藏運輸能力等。專家指出用蒙尊法使 果皮增厚是比較次要的工作，而且現在所用的方 法並不正確, 用老的品種如本地早作篇接穗, 不 可能得到預期的結果, 蒙導法僅僅對幼年的新的 品種發生影響。今後科學工作者首先要䂰究的問 題應該是生產上存在着的急待解决的問題。

\section{三西南匡}

1.一般情况 西南臨包括四川、雲南、貫州、 西康四省, 按着自然条件約可分第三個主要部分:

（1）四川盆地, 海拔高度 200-700 公尺, 盆地 之內邱陵起伏，河流交錯，氣候温和，全年平均 温度在 $17-20^{\circ} \mathrm{O}$ 之間, 全年雨量約計 1,000 毫
米左右, 土壤以紫色士篇主, 其餘第沖皘土黃壤 與紅壤。農作物以水榣硰主, 次篇玉米、紅落、

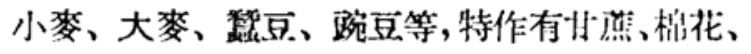
䒺草等, 水果出產以朴枮第主, 次篇梨、濒果、 龍呢、荔枝等。(2) 雲贵高原, 一般游找润度 1, 000-2, 500 公尺, 包括若干小永地, 采㬋濰和, 沒有大寒大暑, 企年雨量約 $1,000-1,500$, 雲南大部分第紅壤, 貴州则以黃壤較多。紅流次 之, 農作物有水缹、玉米、高梁、小麥、冬係豆颣。 果品出産以梨、桃営主, 次第胡桃、板栗、少量 村桔, 南部近亞熱帶透線也產甭蕉、龍呢、咸梨 等。(3) 川康淡唊谷地帶, 山嶺高管, 可到 4,000 公尺, 部分地帶終年寒冷, 在河谷地品叮以低到 1,000-2,500 公及, 氣候文較篇温和, 丽量分倠很 不本均, 西康南部從 750-1, 500 笔米, 但北部有

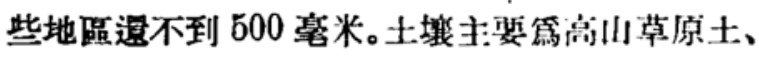
泡炭土、灰棕壤等。濃作物有馬鈴掏、青稞、小麥、 大麥等, 牧音生產佔主要位置。水果产量不多, 有梨、桃、李、胡桃等, 陝谷低地有少量榯桔出産。

2. 果樹種類 全區果品生產以材桔類笘主, 大量分佈地點在四川。在柑桔颣中又以紅枮数量 最多, 次篇甜橙和柚, 䛪檬僅有極少量出浐, 梨 和蘋果産量也不多.

紅枯主要颜卧篇合川、汇津、巴絲、金堂、

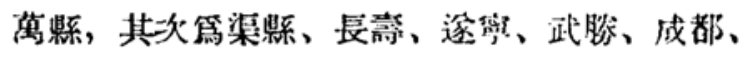

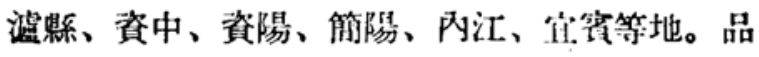
種有無核紅桔、硃砂紅枮、江沾材、大紌抱、小 紅被、香柎等多種。全年湹量約有 47 满担。

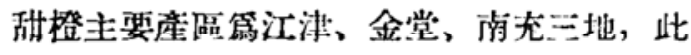

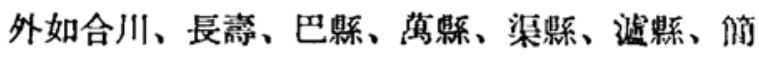
陽等地栽培也很多。甜橙在四川俗称愿柎, 在雲 南叫作黄果, 可分䉆鹅蛋形、同球形、而回形三

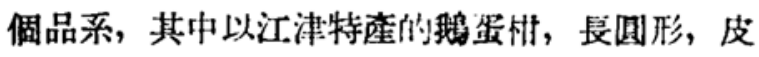
薄子少, 柎酸適度是四川最俊主们品系, 又如趙 鋇紅毛甜撜和黄毛甜橙, 品资均份好. 全年産量 的有 25 淢担。

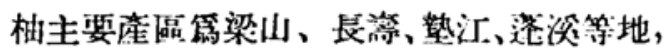
其中梁山佃、辰瑇沙时柚、左氏柚是較第知行的 品種。全年漟量約三葛坦。

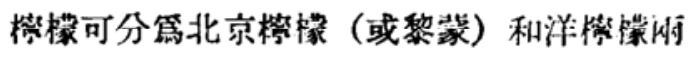
類, 北京復櫒較第酎寒, 但酸度香味都不及洋你

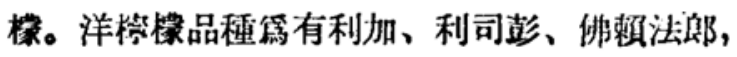


近年才輸入重庱附近裁培, 產量不多。

梨在本區中品種很多, 分佈很廣, 但産量不 大。四川産區在荅添、簡陽、惁功、成都、宜賓、 萬縣、富順等縣，其中以苍添梨、金川梨的品質較

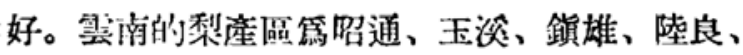
大理、呈貢等地，其中以貿珠梨品質最好。西康

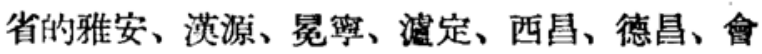
理均産梨，其中以漢源梨較䈔知名。

蘋果在西南區茷培不多, 僅見於四川省成 都、華陽、濩縣、茂縣、汶川、遂塞、安岳、巴 䇣等, 其餘在昆明、贵陽附近有極少量出產, 常

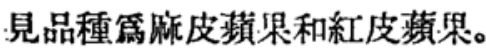

龍哏、荔枝主產在四川省南部的㮴縣、合

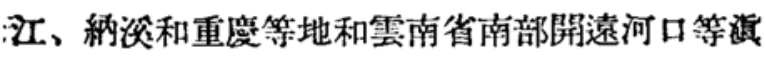
越邊境。香蕉近年在重度附近試種成功, 已有少 量生產。

3.經營情况 本酷果品種頪踓多, 但以村桔 最佔重要位置, 成䉆當地農村重要副彦之一, 有 些地品把果樹作專業裁培, 相當農業收入的 $1 / 4$ 至 1/2。解放前統計 (1935-40 年) 四川全年

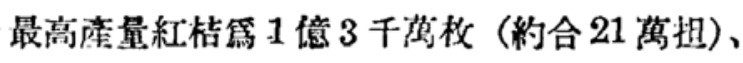

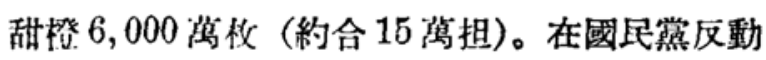

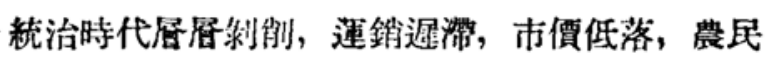
無意經營, 多年未會治就旅肥, 産量鋭減。

解放三年隶人民政府探取坆復與發展的为

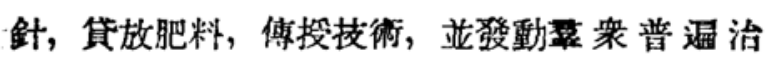

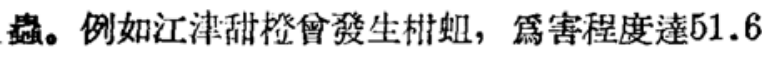
\%, 經大力動員㧝防治後, 1951 年已減少到 $30 \%, 1952$ 年僅饤食 $10 \%$ ，可望全部消诚。加以 自 1951 年起, 甜橙有一部分外銷, 大大的提高

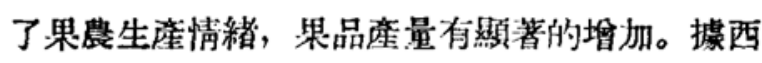
南農林部初步統部, 全區果品總颜 量 1952 年: 約

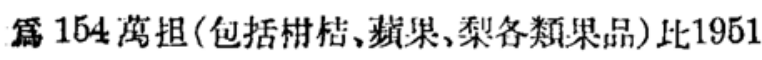

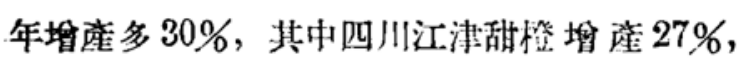

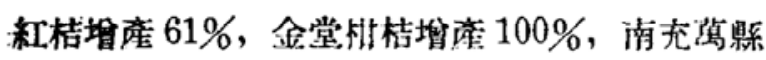
的柑桔均㘿加 $50 \%$, 其餘大部分地區果品崖 都已達到戰施的技学水本。

4.存在問題 恵家在重度北礠、江津、成

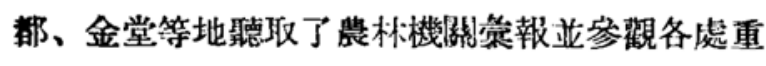
要的園藝試䮄場、朴桔包裝廠、加工廠、宸學院、

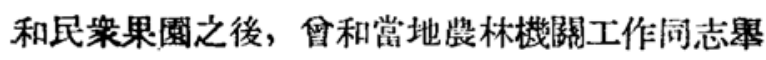

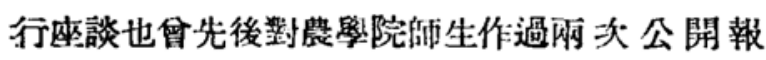

告。他倗指出四川在經營果品生産中存在的故多 技術問題, 也提出今後發展應取的方向。

專家認第四川有废䦔的川區, 發展 朴桔 事 業, 前途希空很大。他們会經叙迌了葆聯在格魯 吉亞發屡村桔的歴史。在十月革命以前, 格魯吉

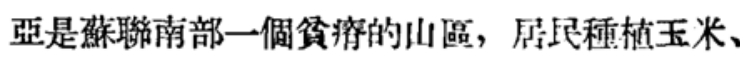
豆類, 啁養山羊, 生活很苦。近黑海岸地區有少

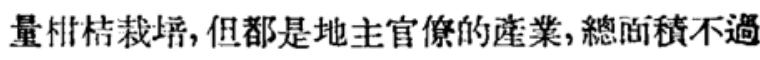
160 公顷。革命後第一個五年計劃决定在通個 域內撥展亞熱帶作物。在沙皇時代俄國每年要花 1,200 萬盧布向其他國家螨買水果, 所以在格答 吉亞地方首先成立森桔苗围, 大量培育㽜木, 贯 款給農民並組成集體農莊载植相枮, 有些地方種 植茶絜。闰時在這區域內設置加工廠, 將不好的

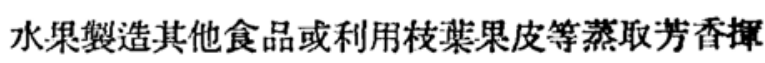
撥油。另外在此虽中成立了十個以上的科學機 關, 専阿研究柑桔作物。由於以上的措㯰, 二十 年後的格魯吉亞由箈困戀篇富足了, 有些辳菲荘 員已經有了自己的汽車, 過着富裕的生活, 人們 早已忘記了玉米餅的滋味。現在格蟹吉亞的柑枯 面皘已經由 160 公頃撗充了三英公頃，每年可萑 梅桔 20 境倜。此外茶棐種植也已援克了六萬公 頃。不要忘記, 蘇聯境內一般氣温較低, 必須制 定一套特殊的载培技術, 间時要選出一些酎寒的 品種, 適應裳地的自然佟件。這些成就的獲得, 是和斯大林同志對水果生產事業的閔心和指示分 不開的。四川江津有些地方很像格鲁吉亞, 且在 自然佟件比格算吉亞好, 以後叮能發展成第四川 相榙生産的中心。

求家指出: 第了供雄外銷, 四川今後發展果

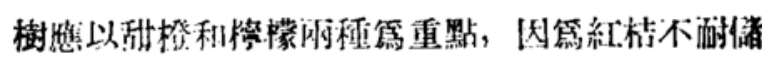

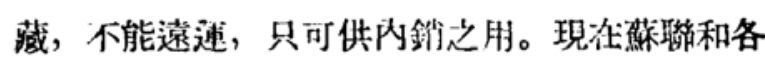

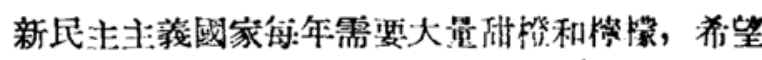
中國能够供給這一類果品。不過现在川川费家所

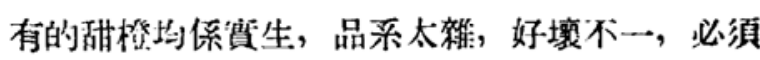

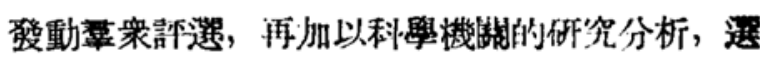
出三、无個品䝯優良和産量䁷富的品系, 大量策 殖, 才能使此種果品商品化。現有的北京㴔撑香 味不够, 酸度太低, 可以不必大量然愐, 應該酸

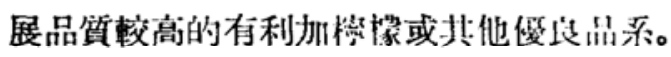

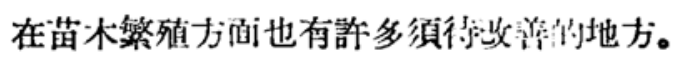

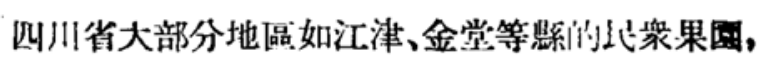

6 月號

科學通報

- $13 \cdot$ 


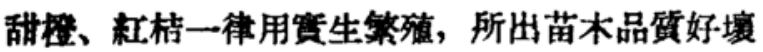
不一, 結果年龄很幄。川北南充等地探用筒靠或 璱土裳枝的方法, 繁殖出來的苗木欺量有限, 大 小很不整齊, 今後第了大量生產提高品貎, 必須 改善繁殖技術, 先選定優良母樹作接穂, 並培䔄 大批優良砧木供嫁接之用。

現在四川一般果樹所用砧木, 種類很多, 有 些很不合適。今後應該由科學機關加以研究試

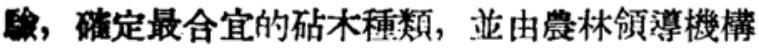
批准推行。以村梏第例, 在蘇聯第了抗寒多用枳

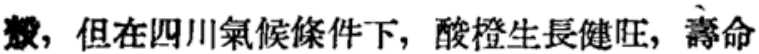

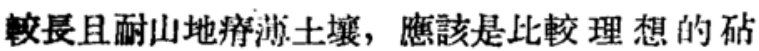
木。現在四川的濒果和梨的砧木用秋子和棠梨, 都是從山野探挃來的老根或分宷繁殖的幼苗, 今 後一定要改用健全的賽生塌。米丘林的名言: “果 樹的砧木有如屋基, 基礎不好, 將來不會有發展 前途。”

在栽培技術方面，果樹裁植距離各地疏密不 一, 遗必須加以研究比較。有些山區果樹行距加 豈, 間作其他作物, 可以照䫏灙民糧食。一般地湂 樹冠管理太忽親，更沒有與施肥配合，所以單株

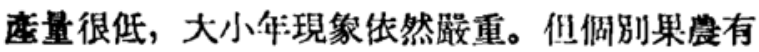
些能够学握施肥技術, 每年都有高額产量。例如 金堂張升禹有甜橙 18 株, 最近三年隡量都是三、 四千斤，平均每株 220 升。又如成都爛泥瑇赖世 榜在五.十年的柑桔樹園中每年春夏兩季施肥，與 一般果湤在冬季施肥方法不同, 他每年產量可比 一般果展高一倍。專家建議科學工作者應該總結 他們的豐窗經䮑再加以分析提高, 並推廣給其他 偖民, 四川省的相桔生產便可比現有 產量增加 二、三倍。

現在民臬果国仍然個別生産分散經營, 今後 應颜廣泛建立互助組，進入合作經營。成都附近 亘家山有一储三百餘嘼規模良好的地主果園, 在 土改後分給屡民, 每家分得了二、三十株, 塄件 衰情踓好, 但工作周未作完, 若能在政府領䢘下

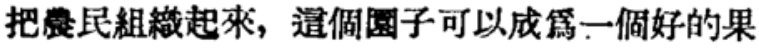
樹生产合作社。對於改進技断, 防治病聂, 使用 新式鹿具等方面, 定有許多便利。

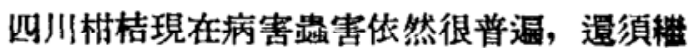
綂大力全䤄防治。金堂縣三作來果樹死亡在一葛 株以上, 主要因篇水災後淤積泥土太厚, 影響樹木
新陳代謝生理平衡，但科學工作者未会予以足姑 重視，造至於不瞭解致死的吉要原因，認爱是根

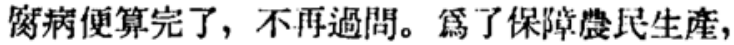
本省科學工作者應裉趕快研究解决辦法, 作緊急 救護工作。

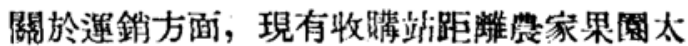

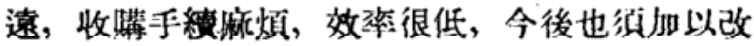
善.

\section{四 中南區}

1. 一般情况 中南區全區地形狄長，自然條 件南北美罢很大。北面從丠沙流域的汇南省, 經 過長江流域的湖北、湖消、江陌三省, 调到珠江

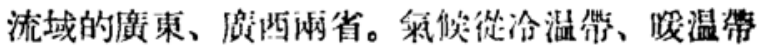
通到亞熱帶。全年本的温度 $15-21^{\circ} \mathrm{C}$, 芷胙雨

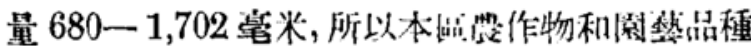

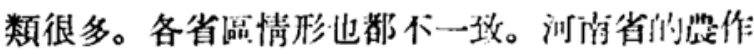
物有小麥、高粮、小米、棉花、菸悲、花生和豆 類, 果樹有蘋果、梨、线、桃、林、板栗、葪萄

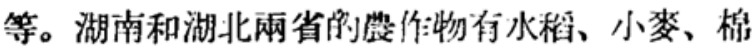
花、花生、俯類，特産茶悲、油桐、水朴，果樹 以柎桔篇主，有少數梨、桃、李、枇杝等。雨度 農作物以水程篇主, 一仵兩熟或三熟, 甘蕉、黄

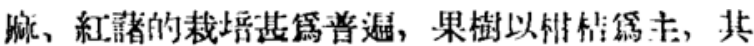
他熱帶亞熱帶水果如香焦、鳳悡、龍哏、莎枝、

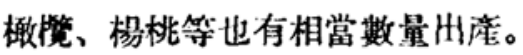

2. 果樹種類 本區果樹以柎枮第主, 是全國

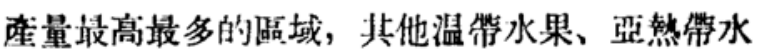
果都具備。

“柎”與“桔”兩個名稱在我國各地方使用含義

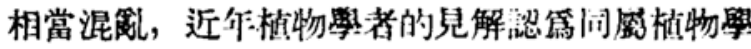
上的一種中的若干變種或雜種, 此地合作在一起 叙述。至於甜橙、柚等並非间種, 所以下面分別 叙述。

中南區各省的村桔類, 品種品系相當被雜, 果質品質相菱很多，其中以廣東省潮汌區特产的 蕉标、榎材，锫酸適度，品質最好，成熟期在十二

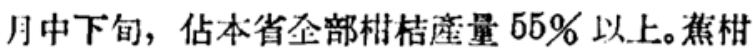
很像甜橙和村枯的雜種, 品系很多, 就果望形狀 分, 有圆形的, 有長国形的; 就果枝言, 有粗 皮、細皮之分。椪㤔也所汌頭篮恻，汒多味甜，風

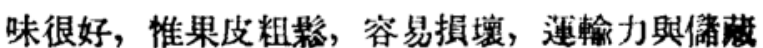


少邀遠不如焦柎，是一假大缺點。兩種分布地區

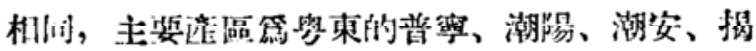

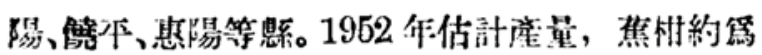

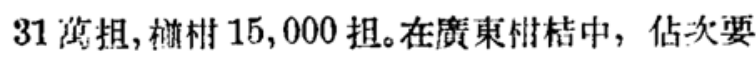

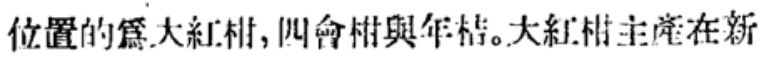

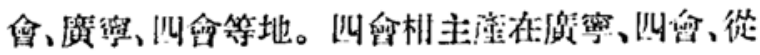
化等縣, 仍枯產於新會、從化和废州附近各地。

湖南產档桔的區域分布在沅江流域和洙水流 域雨岸, 以衡山的草枋和潡浦学最主要產區, 其 次営江江、郡陽、沅江、長沙等地。品種以大紅 袍最篇曹避, 産量很多, 佔本省材桔産量牛数以 上, 但種子數多, 品質不太好, 又不酎储藏是其 缺點。

江西相桔分布在䇉江和汗江兩岸，以新洤三 湖區的九月黄朱桔、南㽞蜜枯篇主要品種。

湖北湘桔分布在長江兩岸和晒川省交界地 帶, 其中甜桔、酸桔、冬桔均產於宜都, 宜昌剓 蹭各有少量出産。

甜橙, 在廣東多分作在藇中區如新會、累禺、

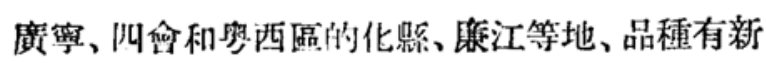

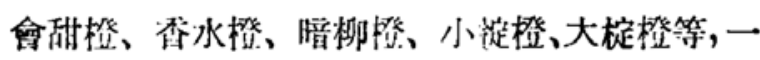

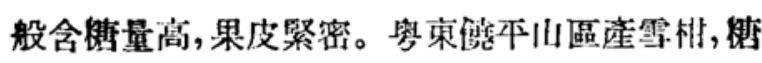
酸適度, 皮薄子少, 品質很好, 總醋量不多, 全 尔僅有三、四千担。

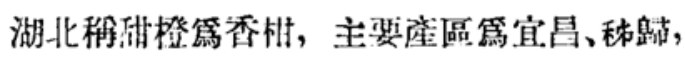
宜都也有少量。香快品系很多, 果形有長有泪, 也有其䑏或太極圖者。

湖南甜橙的主要產區篇衡山草才湤浦、庭 淡、邵陽。

柚主產在廣西省, 佔全省栍桔類蚉量 $90 \%$ 以

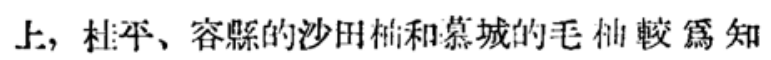
名。此外在江西省的䇉江、䀒江, 湖南省的黑江、

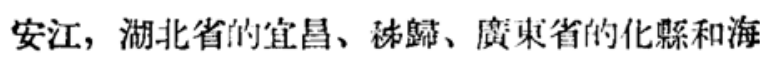
南島等地均成湖。

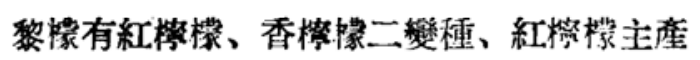
廣東省的新會、中山、番禺, 以前算有大量洲口。

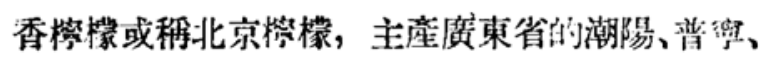

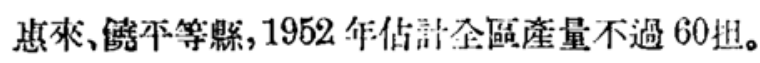

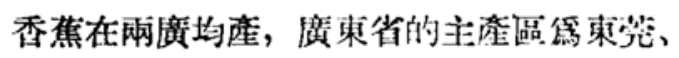
中山、順德、番禺、新會、增城, 品程有否蕉、 大蕉、龍芽蕉等。廣酒省分布柞荅梧、藤懸、消 察、桂平一帶, 有香蕉、大蕉、鷂蕉、西貢蕉等

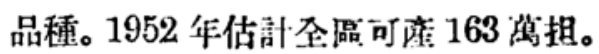

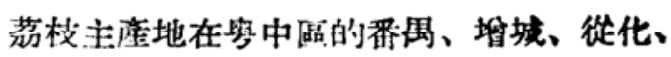

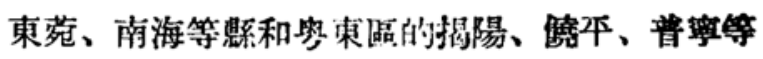
䇣。重要品種早熟的有三月紅和水東品柴, 中熟 的有品渠, 王荷包, 晚熟积有甜岩、柆味、准枝、 精䊖枝等。企年产量約 75 葛担。

龍眼主產地在然中區的中山、東范、霜禺、

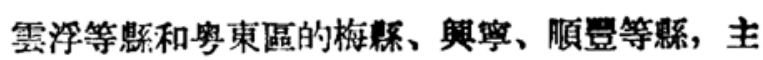
要品種有石峽、烏圆花殻。全年産量約 21 萬担。

波維或稱鷍梨, 主産地第海南岛的文昌、定安

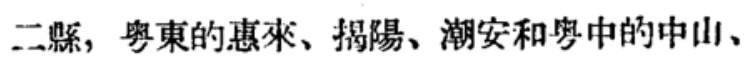
番禺、害安、東苑、高要等縣。常見品種可分第 二類, 本地種渠透有制, 夏威夷種集遥光渭。全 區年应量約 45 藻担。

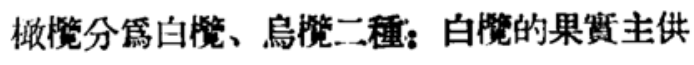
生食, 也可以監清加工, 運銷廣州、上海、香港、澳 門以至南洋一帶。廣東、廣西兩省南部所陵地带 均有㘺堌。不酎寒, 在廣東省英德以北即少見。鳥 管可以監資或作蜜㧱, 果闪可以榷油, 核仁可食,

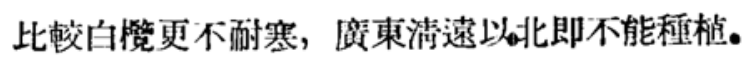

以下再略淡在中南區果樹生產中育量较小, 佔次要位置的幾種落装果樹:

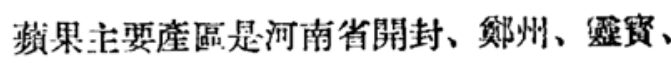
汝南一帶，其次篇变陽、桀城等地。品種以倭錦、 國光、絸丙等較多, 其次䉆青香蕉、秋花皮等。

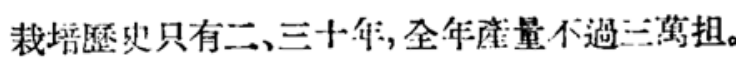

梨在本區分布很度, 從河南到廣東各處都有。

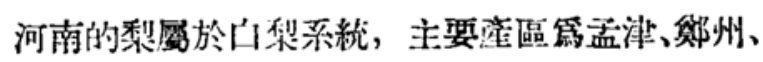
洛陽、泌陽、閉叔等地, 往南則多数屬於砂梨系 統, 廣東有淡水梨, 品質昴好。

相在本區分布也很廣, 從河南、湖北、湖南 一直到展東等省, 產量以河南较多, 用作柿餙、

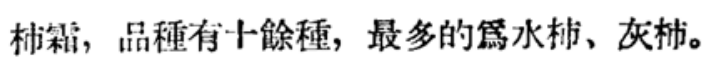

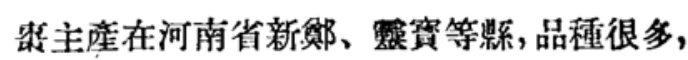

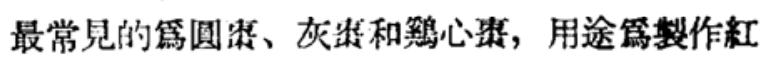

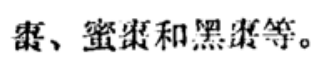

李在本區分倠㸃遍, 產量不多, 河南有牛心 李、洛河李, 湖南有硃砂李、金堂李, 㲊東有南 華李，算是比校绶良的品稺。

3. 經營情况 廣東省是我國亞㠇得水果的主

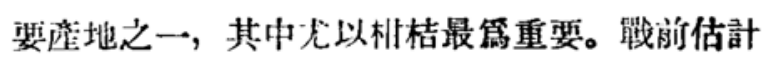

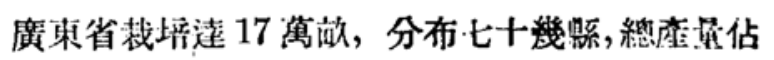


全國産量的三分之一。廣東省村枮生產發展的 原因, 除去榎越的自然條件以外, 果桪辇培歷史

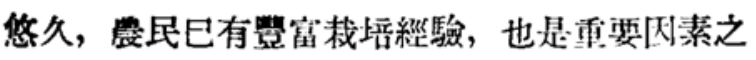
一。在寒束如普窂賔鏡院村、潮安陌林村等地的

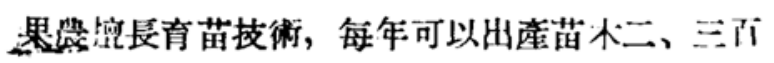
藻株, 遠銷到廣州、漳州、以及台湗香港等地。 他們在繁殖和裁培上遠遠地超過了㱖培糜史已久 的化縣、獜江等地。在赑束區中焦村定枌，第二 年即可開始結果, 到了第三年健叮以得到很敲

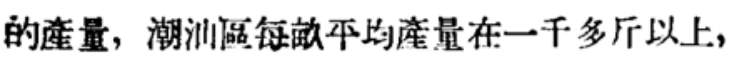

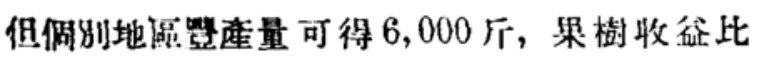

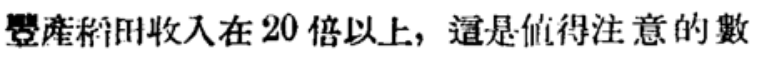
守!

古抗戰期間潮汌區域沿鐵路雨侧很多大片的

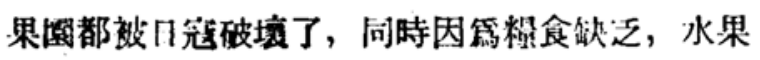

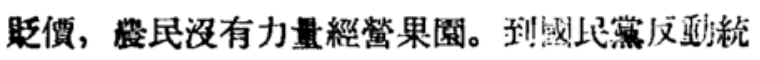
治時期, 我國方場有大批美國朴棺倾銷, 图產柱 柁更找不到出路，所以产量連尔经娍。

解放以後, 中南農林領薄機構看到了果樹生

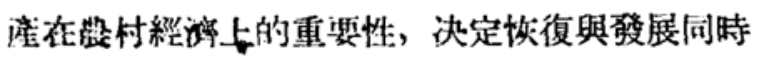

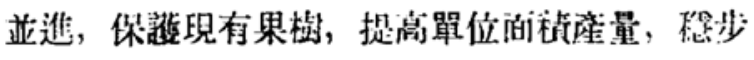
發展一些銷路好、有長遠前途的果樹, 例如朴桔、 零蕉、風悡、荕枝、龍眼等等。共中, 枮枮一项 1951'年起即闰始外銷, 由土库公司規定合理槚格, 大批收䁚, 分級包裝運銷國外。兩作:以來各地種 植果樹面皘有䫏著的坦加, 以潮汕區而論, 根據潮

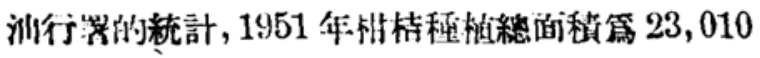

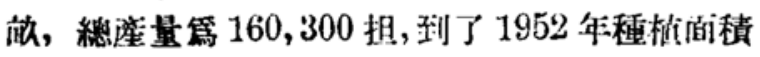

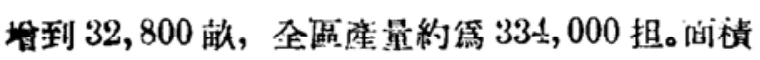
增加了 $43 \%$, 侪量方面增加了 $108 \%$ 。

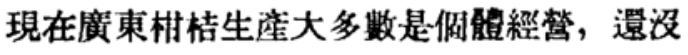
有走上方助合作的形式。但個別果農中也有一些

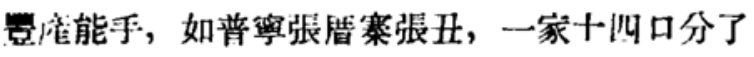
水归 10.5 计, 果園 4.6 敬, 有蕉柎約 1,200 株,

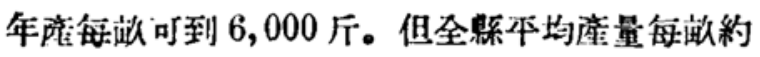
1, 500 斤, 這倜數目在全國範範講不能算低, 若從

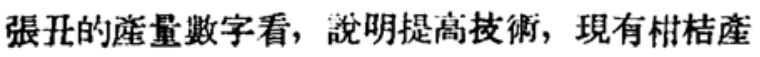
量立刻可以提高兩三倍!

4. 存在問題 䙳家根據在湖北省㔬昌、废東

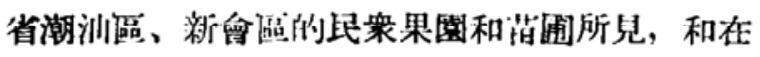

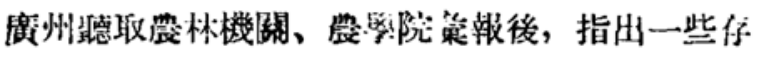

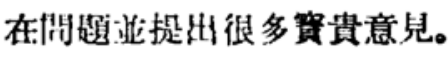

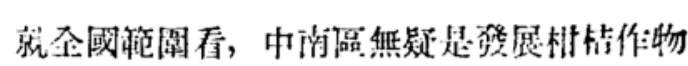

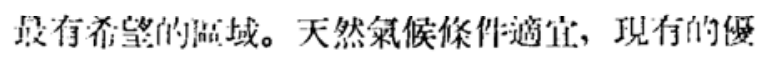

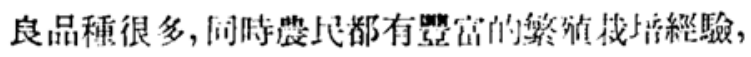

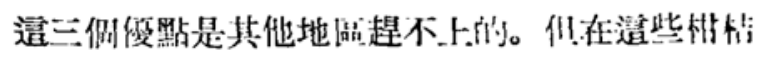
品種中, 仙括吘多混雜的品系, 品質好滾相学很

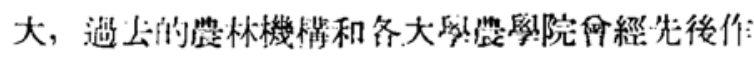

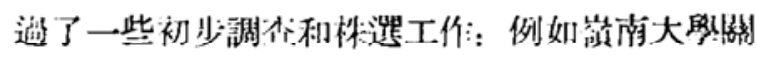

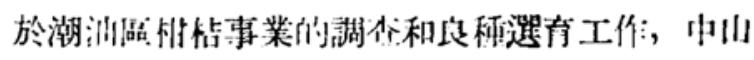

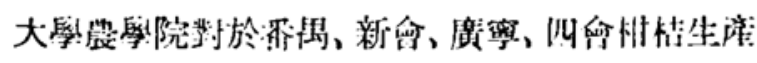

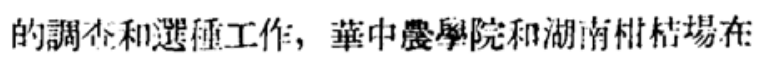

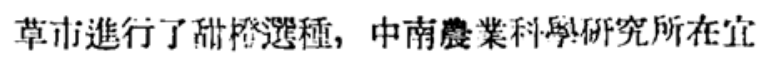

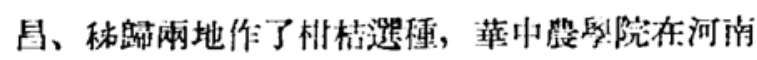

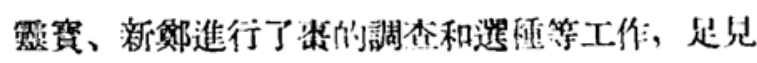

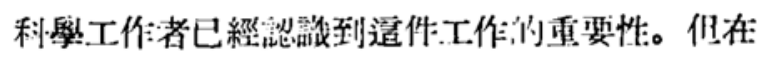

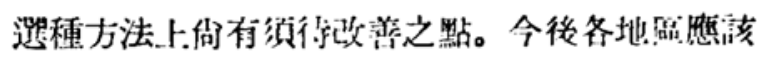

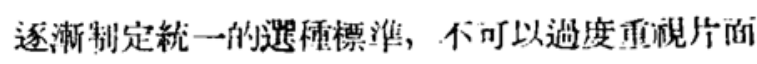

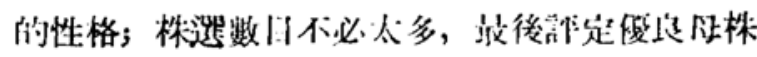
每品系二、三十株已足矽繁斿之用。技血要的是

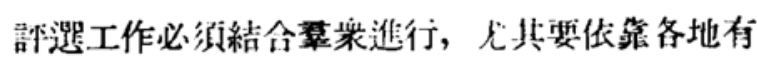
經驗约勞翻模範與科學工作: 者期沁工作。

篇了保持果樹品種的俊怎性格, 掊有大批僈

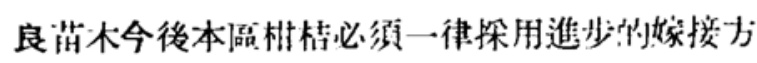

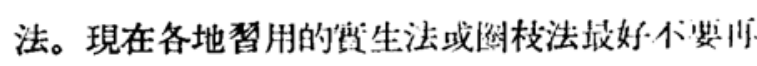

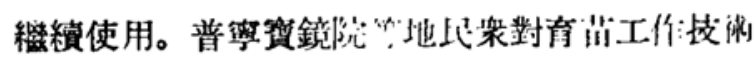

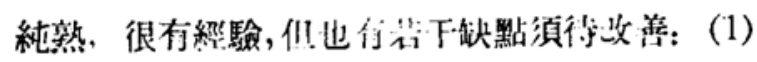

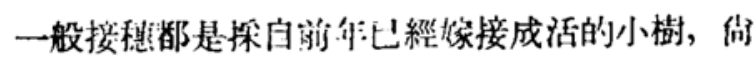

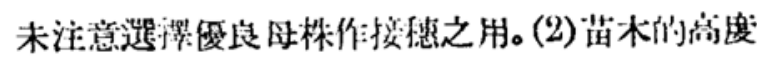

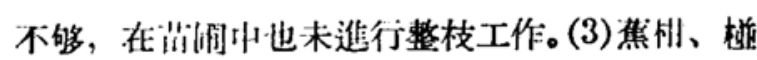

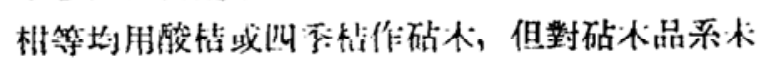
加選橴。(4) 過去菏木媱了適應低地截培, 在苗 阎中要貫行曲根手櫝, 今後朴桔向川地㟋展必須 改用遖根, 使苗木能有強大深入的根系, 尘叮以 抵抗風災和防沾乾崇。

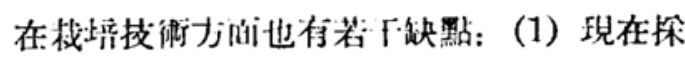
用的株行距太泌, 例如潮防等放種枯樹約 200 株,

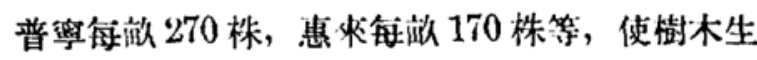

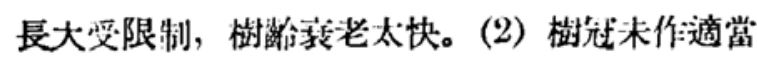
的修学, 捜容易發生大小年現象, 不易得到最高 浐量。(3) 絬果伎末作適當的更新工作，樹龄大

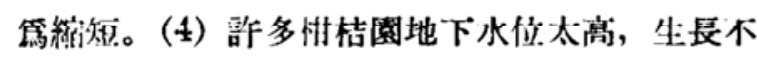

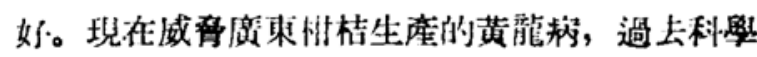
工作者走了很多路源水船决, 笔無絬果, 今後 
热該從改良裁培技術入手。

今後中南區果樹必須向山坡地上發展, 這項 工作具有多重意義:（1）山區果樹生長健些，樹 䶖長遠, 山區果實品質良好, 成熟期長, 储運力 都此平地產者較好;（2）藵出廣大平原地活可以

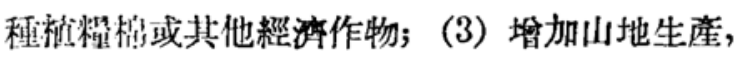
收善山剾人民生活。不過在果樹上山之前, 應該 調查研究並制定一套山區栽培技街, 過去在作原 上使用者不能硬搬上山。必須選澤適合山區生長 的砧水和果樹品種。以焦林論, 最好能選出一個 品缶好而熟的品系, 在入冬以前可以探摘, 這 樣便可以減免冬季乾旱的威角。此外應特別注意 山區水土你持工作。

荔枝是廣東特産優良果品, 在山呈中有四、五。 百年的大樹而且遌續有原量, 證明荔枝是適於上 山的果樹之一。根據華南農學院邵堂年敎授觀祭 報告, 崽枝在十二月温度低時, 第三年年量便 高, 若十二月温度高時, 大年產量要降低, 這也 說明苏枝花芽分化需要較低温度, 今後最好向山

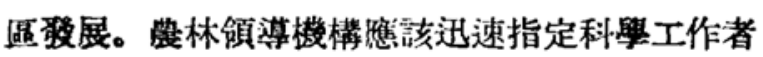
洋細研究葱枝的生物學特性和栽培技術, 以便大 量在山踠推廣。

㷅後篇工作的聯繁問題, 今後第了搹好柑桔 生產工作, 不僅農林領荨機構和科學工作者要與

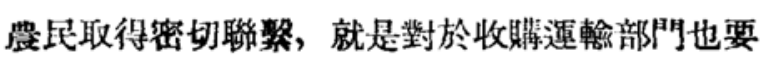
經常與各方面取得聯繁。因第外銷工工作是一㮯新 任務, 從探摘到包装運銷都需要一定的技術。我

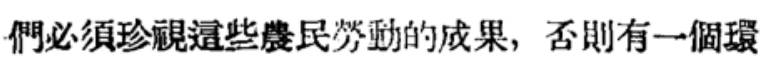
篩發生了問題, 便會使農民和國家財產遭受鉅大 損失。

\section{結}

從以上各大區果樹種類和分布情形看來, 在

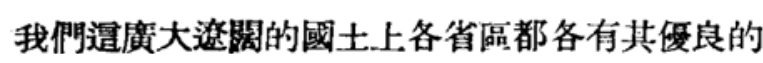
果品生崖。今後應作廣泛而深入的調查並就各地 固有的侵良品種, 加以發展, 因地制宜不必强求 一律, 使果品生颜區域化。

不過在我國固有的果樹品種中, 常有很多混

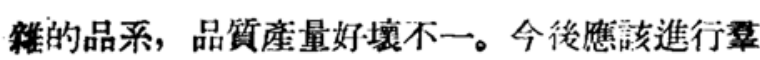
衆钎比與科學調柋分析相結合的株選工作。每一 區域中同一種或品種, 株選數目不要太多, 每一 品系, 二、三十株, 注意品質好、鏟量高、供應
期長、且耐儲藏運輸的三、五偑品系，選定嗳良母 株, 大量繁殖推廣。這樣才可以使果品商品化。 根據浙江、四川、廣東各地所見，山品糢樹 一般較平原所產的品質好, 樹薮長, 病蟲害較少, 所以今後我國果樹種榷, 應該向山品發展。各地 晨林领導機構和科學工作者應該調查研究並制定 一隹山渷裁培技術，並選定適合山區生長的果樹 種類和品種。

日前各地果樹病害蜼害情况相當嚴重, 農林 領導機構應該指示科學工作者研究各地病蛅發生 規律, 制定徹底防除病蜎害的方法並由有關部門

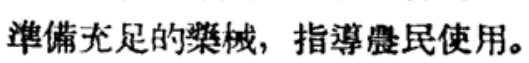

各地果樹隔年結果現象依然很㙳重, 今後應 從裁培、修前、施肥等一系列的技術上解决。科 學工作者必須研究各種果樹的生物學特徽, 如果 樹結果替性、花芽分化時期等和䍚業技術原理, 有了正確的理諭研究, 才能指䢘技術, 以推進實 際的生竰工作。

各地在繁殖苗木工作上, 多數注意在數量上 完成任務而忽浣了苗木的品質。改善嫁接技術,

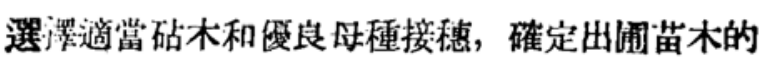
规格, 是保登優良苗木的必要措施。

在推廣種植工作中, 同時注意收購迋銷粗䋘、 交通條件和必要的加工設備, 以保證果腆的收谷。

“組織起來,搞好·生产”, 在果樹生產无其重要, 但在全國範園內除東北區已有若干合作互助的粗 樴以外, 其他地區多數是個别經營, 今後䧺該在黨 的領導下, 組織果農由各種不同形式的互助組逐 漸成篇生育合作社, 使果樹生産逐漸走上集觰化。

各地祳林機構和科學工作者必須重視和總結 果農䇺蓙經驗, 並在科學基礎上加以分析提高, 然後再推廣給一般果丵普遍應用。

今後園藝科學工作者必須堅持米丘林科學的 方向, 正確地貫徹科學理論與生产賽践相結合的 方針，有效地選捽培育優良果樹品種，並改善現 有果樹裁培技術，解决現在生產上迫切需要解决 的問題。

第了配合國家的大規模經橓建設的需要, 第 了涩足廣大人民對於科學技術的迫切要求, 讙我

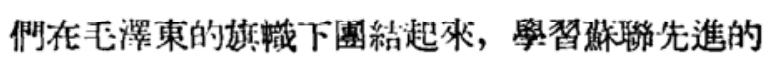
利學理論和技術, 篇改進我國的農業園爇生产而 努力! 